\title{
'Candidatus Mycoplasma haemoalbiventris' and tick-borne pathogens screening in white-eared opossums (Didelphis albiventris) from Curitiba and Foz do Iguaçu Cities, Paraná State, southern Brazil
}

\author{
'Candidatus Mycoplasma haemoalbiventris' e triagem para patógenos \\ transmitidos por carrapatos em gambás de orelha branca (Didelphis \\ albiventris) das cidades de Curitiba e Foz do Iguaçu, Estado do Paraná, sul do \\ Brasil \\ Renata Prestes Antonangelo de Oliveira'; Flávia Carolina Meira Collere'; Larissa Dantas Roeder Ferrari; \\ Vanessa dos Santos Coradi ${ }^{1}$; Nathália de Albuquerque Soares ${ }^{1}$; André de Souza Leandro². \\ Wagner Fabiano de Oliveira²; Sandro Roberto Galvão²; Rosinei Kafka²; Robson Michael Delai; Rafaella Martini; \\ André Saldanha ${ }^{1}$; Leonardo Pereira dos Santos ${ }^{1}$; Zalmir Silvino Cubas ${ }^{5}$; Rogério Ribas Lange \\ Thállitha Samih Wischral Jayme Vieira'; Rafael Felipe da Costa Vieira1,6* (B) \\ 'Laboratório de Doenças Transmitidas por Vetores, Departamento de Medicina Veterinária, Universidade Federal do Paraná - UFPR, \\ Curitiba, PR, Brasil \\ ¿Unidade de Vigilância em Zoonoses, Secretaria Municipal de Saúde, Foz do Iguaçu, PR, Brasil \\ ${ }^{3}$ Laboratório de Saúde Única, Centro de Medicina Tropical das Três Fronteiras, Fundação Itaiguapy, Instituto de Ensino e Pesquisa, Foz \\ do Iguaçu, PR, Brasil \\ ${ }^{4}$ Departamento de Medicina Veterinária, Universidade Federal do Paraná - UFPR, Curitiba, PR, Brasil \\ ${ }^{5}$ Médico Veterinário Autônomo, Foz do Iguaçu, PR, Brasil \\ ${ }^{6} \mathrm{Global}$ One Health initiative - GOHi, The Ohio State University, Columbus, $\mathrm{OH}$, USA
}

\begin{abstract}
How to cite: Oliveira RPA, Collere FCM, Ferrari LDR, Coradi VS, Soares NA, Leandro AS, et al. 'Candidatus Mycoplasma haemoalbiventris' and tick-borne pathogens screening in white-eared opossums (Didelphis albiventris) from Curitiba and Foz do
\end{abstract} Iguaçu Cities, Paraná State, southern Brazil. Braz J Vet Parasito/ 2021; 30(4): e009721. https://doi.org/10.1590/S1984-29612021072

\begin{abstract}
Hemoplasmas are epierythrocytic bacteria that infect mammals. 'Candidatus Mycoplasma haemoalbiventris' was detected in white-eared opossums (Didelphis albiventris) from southern and central-western Brazil. The present study aimed at: i) screening opossums for tick-borne (TBP) pathogens (Piroplasmida and Anaplasmataceae) and ii) detecting and characterizing hemoplasma species infecting opossums from Curitiba and Foz do Iguaçu cities in the Paraná State, southern Brazil. Thirty blood samples from white-eared opossums were evaluated by PCR assays. Animals were not infested by ectoparasites. The mammalian endogenous gapdh gene was consistently amplified in all samples. All opossums tested negative for Theileria/Babesia spp. and Ehrlichia/Anaplasma spp. by PCR based on 18S rRNA and 16S rRNA genes, respectively. A genus-specific PCR assay based on the 16S rRNA gene of hemoplasmas showed that three/13 (23.08\%; Cl 95\%: 8.18-50.26\%) opossums from Foz do Iguaçu were positive for hemotropic Mycoplasma sp. All opossums from Curitiba tested negative for hemoplasmas. Sequencing of both the $16 \mathrm{~S}$ and $23 \mathrm{~S}$ rRNA genes revealed that the animals were infected by ' $\mathrm{C}$. M. haemoalbiventris'. Although ' $\mathrm{C}$. M. haemoalbiventris' is prevalent in opossums in Brazil, clinical signs associated with its infection and its putative vectors remain unknown.
\end{abstract}

Keywords: Marsupials, hemotropic mycoplasmas, hemoplasmas.

\section{Resumo}

Hemoplasmas são bactérias epieritrocíticas que infectam mamíferos. 'Candidatus Mycoplasma haemoalbiventris' foi detectado previamente em gambás-de-orelha-branca (Didelphis albiventris) das regiões sul e centro-oeste do 
Brasil. O presente estudo objetivou: i) triar os gambás para as doenças transmitidas por carrapatos (Piroplasmida e Anaplasmataceae); e ii) detectar e caracterizar as espécies de hemoplasma que infectam gambás nas cidades de Curitiba e Foz do Iguaçu, no Estado do Paraná, sul do Brasil. Trinta amostras de sangue de gambás-de-orelha-branca foram analisadas por PCR. Os animais não estavam infestados por ectoparasitos. O gene endógeno de mamífero gapdh foi amplificado em todas as amostras. Todos os gambás testaram negativos para Theileria/Babesia spp. e Ehrlichia/Anaplasma spp. por PCR, respectivamente, para os genes 18S rRNA e 16S rRNA. Uma PCR gene-específica, baseada no gene 16S rRNA de hemoplasmas, mostrou que três/13 (23,08\%; Cl 95\%: 8,18-50,26\%) gambás de Foz do Iguaçu foram positivos para Mycoplasma sp. hemotrópico. Todos os gambás de Curitiba testaram negativos para hemoplasmas. O sequenciamento de fragmentos dos genes $16 \mathrm{~S}$ e $23 \mathrm{~S}$ rRNA revelou que os animais estavam infectados pelo ' $C a$. M. haemoalbiventris'. Embora 'C . M. haemoalbiventris' seja prevalente em gambás no Brasil, os sinais clínicos associados à infecção e os prováveis vetores permanecem desconhecidos.

Palavras-chave: Marsupiais, micoplasma hemotrópico, hemoplasmas.

Opossums are synanthropic marsupials belonging to the genus Didelphis. In South America, four species have been reported: D. albiventris, D. aurita, D. imperfecta, and D. marsupialis (Nascimento \& Horta, 2014). Due to their circulation in urban and rural environments, opossums are potential hosts, suggested reservoirs and/or potential amplifiers of infectious agents (e.g., Trypanossoma cruzi, Leishmania infantum, Rickettsia rickettsii) (Horta et al., 2009; Carreira et al., 2012; Zecca et al., 2020).

In Brazil, tick-borne pathogens (TBP) have been reported in Didelphis spp. from different regions (Melo et al., 2016; Soares et al., 2017; Guimarães et al., 2019). This includes a novel ehrlichial agent, Ehrlichia sp. strain Natal, detected in white-eared opossum (D. albiventris) from the northeastern region of the country (Lopes et al., 2018).

Hemotropic mycoplasmas (hemoplasmas) are Gram-negative bacteria that attach to the surface of red blood cells from mammals and may cause hemolytic anemia. Two hemotropic Mycoplasma species have been described in Didelphis, namely 'Candidatus Mycoplasma haemodidelphis' (Messick et al., 2002) and 'Candidatus Mycoplasma haemoalbiventris' (Pontarolo et al., 2021). Due to the proximity of human dwellings and human-animal interactions, monitoring ticks and the health status of opossums is a public health concern. Therefore, this study aimed at investigating the occurrence of TBP and hemotropic mycoplasmas in free-ranging opossums from the Curitiba and Foz do Iguaçu cities of the Paraná State, southern Brazil.

This study was approved by the Ethics Committee for Animal Experimentation and Animal Welfare at the Universidade Federal do Paraná, Brazil (protocol number 053/2018). Animal and laboratory procedures were approved and performed under the regulations of the Chico Mendes Institute for Biodiversity Conservation (ICMBio, protocol number 63433-3).

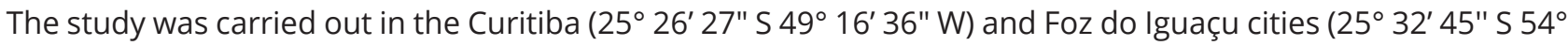
35' 07" W). Curitiba, the capital of Paraná State, is located in the south-central region and has a humid subtropical highland climate (Köppen: $\mathrm{Cfb}$ ) with an average temperature of $17.4^{\circ} \mathrm{C}$. Foz do Iguaçu lies in the extreme west of the Paraná State, on the border of Brazil, Argentina, and Paraguay, in the Atlantic rainforest biome. Foz do Iguaçu is internationally recognized as a protected area with diverse fauna (Valente et al., 2019) and has a humid subtropical climate (Köppen: $\mathrm{Cfa}$ ) with rainfall throughout the year and an average temperature of $22.1^{\circ} \mathrm{C}$.

A total of 30 white-eared opossums (D. albiventris) were evaluated. In Foz do Iguaçu, 13 white-eared opossums were captured using Tomahawk wire mesh traps baited with fruit. Sampling was performed between April and December 2019 per the spontaneous demand of the Zoonoses Surveillance Center, based on the report of the occurrence of opossums in human dwellings. In Curitiba City, 17 white-eared opossums were referred to the Veterinary Teaching Hospital, Universidade Federal do Paraná, Parana State, southern Brazil, between June 2018 and December 2020. Samples from Curitiba were also collected per the spontaneous demand based on the report of the occurrence of opossums in human dwellings.

After using chemical restraints (xylazine $(4.0 \mathrm{mg} / \mathrm{kg})$ and ketamine $(20 \mathrm{mg} / \mathrm{kg})$, the animals were individually identified and visually inspected for ectoparasites (ticks and fleas). Subsequently, EDTA-blood samples were collected by caudal venipuncture and stored at $-20^{\circ} \mathrm{C}$ until molecular analysis. Post sample collection, the animals were monitored until complete recovery from the chemical restraints and later released (Massini et al., 2019). 
DNA was extracted from $200 \mu \mathrm{L}$ of blood using a commercially available kit (IllustraTM Blood Genomic Prep Mini Spin Kit, GE Healthcare Life Sciences, Little Chalfont, UK), according to the manufacturer's instructions. Ultra-pure water was used as a negative control in parallel to monitor cross-contamination.

To monitor DNA extraction, PCR for the mammalian endogenous gene glyceraldehyde-3-phosphate dehydrogenase (gapdh) was performed in all samples (Birkenheuer et al., 2003). Conventional PCR was used to screen samples for hemotropic Mycoplasma spp. genus-specific primers targeting a portion (900 bp) of the 16S rRNA gene of hemotropic Mycoplasma spp. (Hoelzle et al., 2011; Machado et al., 2017). Opossum DNA samples that tested positive in the PCR assay based on the 16S rRNA gene were subjected to a genus-specific PCR assay targeting a fragment ( $800 \mathrm{bp}$ ) of the $23 \mathrm{~S}$ rRNA gene of hemoplasmas (Mongruel et al., 2020). Nuclease-free water and Mycoplasma ovis DNA from a naturally infected goat blood sample were used as the negative and positive controls, respectively, in both PCR assays. Additionally, DNA samples were also tested by PCR assays targeting a fragment (551 bp) of the 18S rRNA gene of Theileria/Babesia spp. (Almeida et al., 2012) and a fragment (349 bp) of the 16S rRNA gene of Ehrlichia/Anaplasma spp. (Parola et al., 2000). Babesia vogeli and Ehrlichia canis DNA obtained from naturally infected dogs were used as positive controls, and nuclease-free water was used as a negative control (Vieira et al., 2013). The amplified PCR products were subjected to gel electrophoresis in $1.5 \%$ agarose gels for 1 hour at 100 V, followed by SYBR safe staining ( $6 \mu \mathrm{g} / \mathrm{mL}$; SYBR ${ }^{\circledR}$ Safe DNA Gel Stain, Invitrogen, CA, USA), and viewed under a UV light transilluminator at a wavelength of $312 \mathrm{~nm}$.

The amplicons of the 16S rRNA (900 bp) and 23S rRNA (800 bp) obtained from three and two Mycoplasma spp.positive samples were from Foz do Iguaçu. They were sequenced in both directions using the Sanger method. Three nucleotide sequences of the 16S rRNA gene and two sequences of $23 \mathrm{~S}$ rRNA gene of hemotropic Mycoplasma sp. amplified herein were submitted to the GenBank ${ }^{\circledR}$ database (accession numbers: MW703800, MW703801, MW703802, and MW694786 and MW694787, respectively).

The consensus sequences were subjected to multiple alignment with the sequences selected from GenBank ${ }^{\circledR}$ using MAFFT available on the GUIDANCE2 server for each gene. The best-fit model of nucleotide substitution was determined using jModeltest v.2.1.10 and was set as GTR+I+G for $16 \mathrm{~S}$ rRNA and TrN+G for 23S rRNA genes, based on the Akaike Information Criterion (AIC), respectively. Each Bayesian reconstruction was performed in Beast 1.10.4 with three independent runs of 100 million MCMC steps sampled at every 10,000 trees, $10 \%$ of the burn-in. The phylogenetic tree was visualized with FigTree software version 1.4.4 and the final layout was done with Inkscape version 0.92.2.

Opossums from both cities were not infested by ectoparasites (ticks and fleas) at the time of sampling. The mammalian endogenous gapdh gene was consistently amplified in all samples. All opossums tested negative for Theileria/Babesia spp. and Ehrlichia/Anaplasma spp. by PCR. While all opossums from Curitiba tested negative for hemoplasmas, three out of 13 (23.08\%; Cl 95\%: 8.18-50.26\%) animals from Foz do Iguaçu were positive for hemotropic Mycoplasma spp., as observed via PCR.

Sequencing of the 16S rRNA fragment showed 100\% identity to 'Ca. M. haemoalbiventris' (MH158514, MH158515, MN423256, MN423258-MN423260, and MT170012-MT170016) detected in white-eared opossums from Brazil; on the other hand, sequencing of the $23 \mathrm{~S}$ rRNA fragment showed $99.74-100 \%$ identity 'Ca. M. haemoalbiventris' (MN442081MN442085) detected in white-eared opossums from Brazil. Phylogenetic analysis of the 16S and 23S rRNA gene fragments confirmed the white-eared opossum were infected by ' $\mathrm{Ca}$. M. haemoalbiventris' (Figures 1 and 2).

In the present study, 23.08\% opossums from Foz do Iguaçu (Paraná, southern Brazil) were positive for 'Ca. M. haemoalbiventris', while all the animals from Curitiba City tested negative. Previous studies have found higher hemoplasma prevalence rates (ranging from 32.5-87.5\%) in white-eared opossums from different geographic regions and biomes (Atlantic Forest and Cerrado) of Brazil (Massini et al., 2019; Gonçalves et al., 2020; Pontarolo et al., 2021). Although Curitiba City is also located in the Atlantic rainforest biome, we hypothesize that its altitude (940 $\mathrm{m}$ a.s.I.) and annual average temperature $\left(17.4^{\circ} \mathrm{C}\right)$ may influence habits and behavior of the opossums, and thus, their exposure to hemoplasmas, which may explain the negative results found herein. Additionally, differences in the prevalence of hemoplasma between studies may have not be due to the diagnostic test used, since to date, all studies on the detection of hemoplasmas in Brazilian opossums have used conventional PCR assays as diagnostic method (Massini et al., 2019; Gonçalves et al., 2020; Pontarolo et al., 2021).

Herein, the animals were not infested with ticks and fleas at the time of sampling. However, hemoplasmapositive white-eared opossums from the Maringá municipality (state of Paraná) (Massini et al., 2019) and Campo Grande municipality (state of Mato Grosso do Sul) (Gonçalves et al., 2020) were infested by Amblyomma dubitatum ticks. On the other hand, opossums from the Canoinhas municipality (state of Santa Catarina) were infested with 


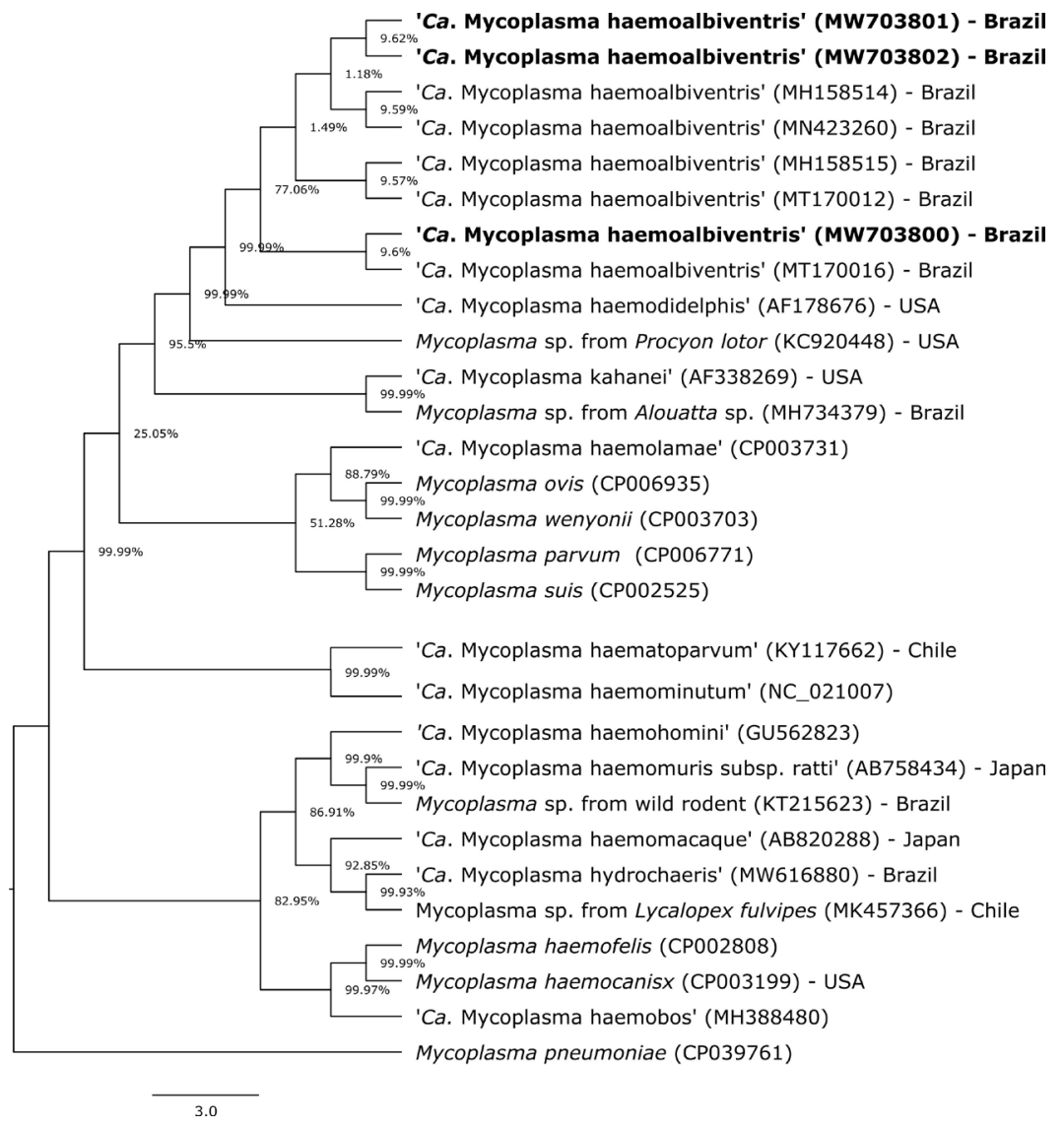

Figure 1. Phylogenetic tree based on partial sequences of the $16 \mathrm{~S}$ rRNA gene, showing the relationship between the 'Candidatus Mycoplasma haemoalbiventris' detected in the white-eared opossums (Didelphis albiventris) from this study and other hemoplasmas. Mycoplasma pneumoniae (CP039761) was used as outgroup. The GenBank accession number is in parentheses after the species name and origin of each agent. Bayesian inferences were carried out applying the GTR+I+G model and 1,000 bootstrap replicates for all analyses.

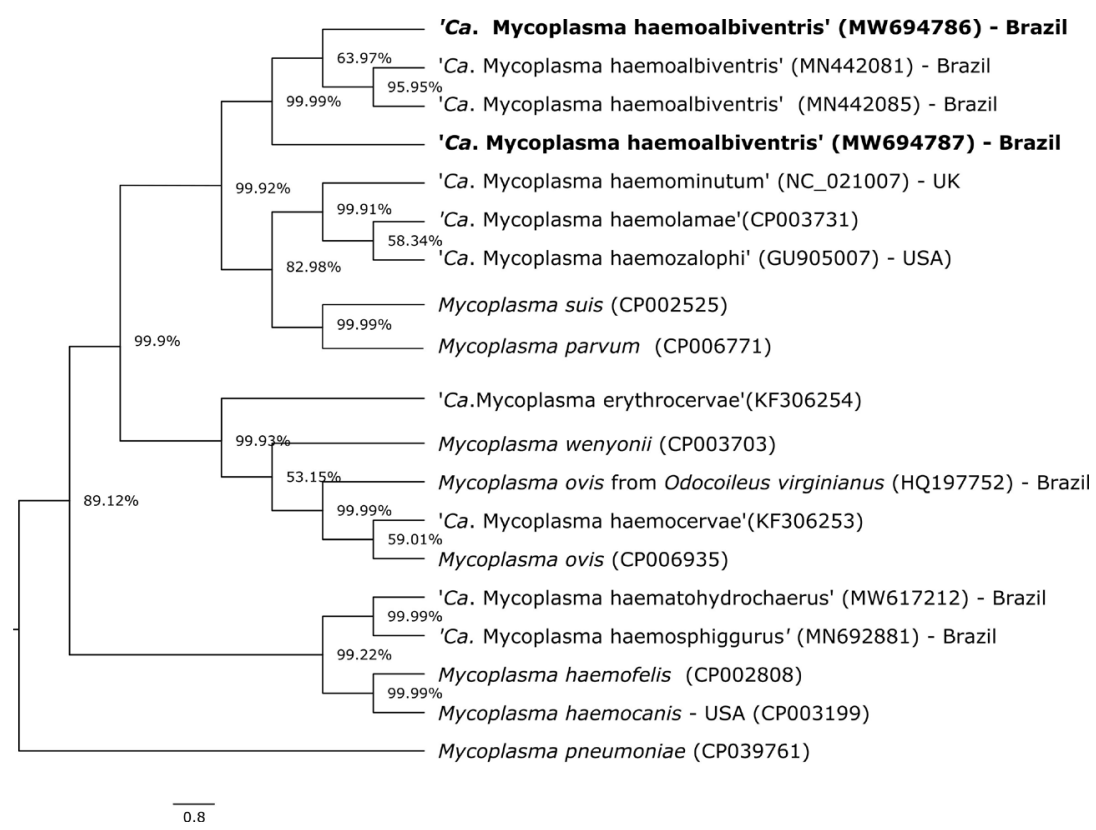

Figure 2. Phylogenetic tree based on partial sequences of the 23S rRNA gene, showing the relationship between the 'Candidatus Mycoplasma haemoalbiventris' detected in the white-eared opossums (Didelphis albiventris) from this study and other hemoplasmas. Mycoplasma pneumoniae (CP039761) was used as outgroup. The GenBank accession number is in parentheses after the species name and origin of each agent. Bayesian inferences were carried out applying the TrN+G model and 1,000 bootstrap replicates for all analyses. 
Ctenocephalides felis fleas (Pontarolo et al., 2021). Previous studies have failed to detect hemotropic Mycoplasma spp. in A. dubitatum ticks infesting 'Ca. M. haemoalbiventris'-positive opossums from Brazil (Gonçalves et al., 2020), and canine hemoplasmas in Rhipicephalus sanguineus sensu lato ticks in dogs from an animal shelter in Turkey (Aktas \& Ozubek, 2017). High hemoplasma prevalence rates have been found in tropical regions, favoring the establishment of arthropod vectors for these bacteria. Additionally, hemotropic Mycoplasma spp. have been detected in Amblyomma sculptum ticks infesting hemoplasma-positive capybaras (Hydrochoerus hydrochaeris) from central-western Brazil (Gonçalves et al., 2020). However, the lack of experimental studies on hemoplasma transmission, due to its uncultivable status in vitro, precludes robust evidence to implicate the involvement of ticks in the epidemiological cycle of this group of bacteria. Finally, A. dubitatum ticks are widespread and have already been found to infest opossums from Curitiba and Foz do Iguaçu cities (Valente et al., 2020). Based on the above evidence, we hypothesize that ticks from this group may have previously bitten animals evaluated in the present study, although we cannot associate the low hemoplasma infection rate found to the absence of ticks.

TBP are of great concern worldwide. In Brazil, Ehrlichia spp., Anaplasma spp., and Babesia spp. have been reported to infect domestic and wild animals (Soares et al., 2017; André, 2018). A novel ehrlichial agent, Ehrlichia sp. strain Natal, has been detected in the northeastern region of the country (Lopes et al., 2018). A putative novel genotype of Ehrlichia sp. has been detected in big-eared opossums (D. aurita) from southeastern Brazil (Guimarães et al., 2019). Morphological identification of piroplasmids (previously named as Nuttallia brasiliensis/Theileria brasiliensis/Babesia ernestoi, and currently Babesia brasiliensis) in marsupials circulating in Brazil was performed virtually 100 years ago (Regendanz \& Kikuth, 1928). Additionally, a novel piroplasmid closely related to a Babesia sp. detected in Monodelphis domestica opossums from the Brazilian Pantanal has been found in D. marsupialis opossums from the Brazilian Amazon (Soares et al., 2017), and another Piroplasmida genotype was reported in two/31 (6.45\%) D. marsupialis trapped in Sinop municipality, State of Mato Grosso (Colle et al., 2019). In the present study, all white-eared opossums tested negative for Theileria/Babesia spp. and Ehrlichia/Anaplasma spp. Although neither clinical signs of infection nor tick vectors have been established for the novel pathogens described in opossums from Brazil, further studies should focus on evaluating this group of marsupials to better understand and characterize the pathogens found.

In conclusion, 'Candidatus Mycoplasma haemoalbiventris' has been detected in white-eared opossums from the Foz do Iguaçu city (Paraná state, southern Brazil), while the animals from Curitiba city tested negative. However, the clinical signs associated with the infection caused by this organism and its putative vectors remain unknown. All animals from both cities tested negative for Theileria/Babesia spp. and Ehrlichia/Anaplasma spp.

\section{Acknowledgments}

This research was funded by Universidade Federal do Paraná (Grant no. 23075.058259/2020-23). This study is part of a PhD degree for Renata Antonangelo at the Universidade Federal do Paraná. Flávia Collere, Rafaella Martini and André Saldanha were sponsored by a fellowship from the the Coordenação de Aperfeiçoamento de Pessoal de Nível Superior (CAPES) at the time of research. Vanessa Coradi and Nathália Soares were sponsored by a fellowship from the Brazilian National Council of Scientific and Technological Development (CNPq). CNPq also provided a fellowship of research productivity (PQ) to Dr. Rafael F.C. Vieira (CNPq - 313161/2020-8).

\section{References}

Aktas M, Ozubek S. Molecular survey of haemoplasmas in shelter dogs and associations with Rhipicephalus sanguineus sensu lato. Med Vet Entomol 2017; 31(4): 457-461. http://dx.doi.org/10.1111/mve.12244. PMid:28685834.

Almeida AP, Marcili A, Leite RC, Nieri-Bastos FA, Domingues LN, Martins JR, et al. Coxiella symbiont in the tick Ornithodoros rostratus (Acari: argasidae). Ticks Tick Borne Dis 2012; 3(4): 203-206. http://dx.doi.org/10.1016/j.ttbdis.2012.02.003. PMid:22480930.

André MR. Diversity of Anaplasma and Ehrlichia/Neoehrlichia agents in terrestrial wild carnivores worldwide: implications for human and domestic animal health and wildlife conservation. Front Vet Sci 2018; 5: 293. http://dx.doi.org/10.3389/fvets.2018.00293. PMid:30533417.

Birkenheuer AJ, Levy MG, Breitschwerdt EB. Development and evaluation of a seminested PCR for detection and differentiation of Babesia gibsoni (Asian genotype) and B. canis DNA in canine blood samples. J Clin Microbio/ 2003; 41(9): 4172-4177. http:// dx.doi.org/10.1128/JCM.41.9.4172-4177.2003. PMid:12958243.

Carreira JCA, Silva AVM, Pita Pereira D, Brazil RP. Natural infection of Didelphis aurita (Mammalia: Marsupialia) with Leishmania infantum in Brazil. Parasit Vectors 2012; 5(1): 111. http://dx.doi.org/10.1186/1756-3305-5-111. PMid:22676324. 
Colle AC, Mendonça RFB, Maia MO, Freitas LC, Witter R, Marcili A, et al. Molecular survey of tick-borne pathogens in small mammals from Brazilian Amazonia. Rev Bras Parasitol Vet 2019; 28(4): 592-604. http://dx.doi.org/10.1590/s1984-29612019086. PMid:31800885.

Gonçalves LR, Herrera HM, Nantes WAG, Santos FM, Porfírio GEO, Barreto WTG, et al. Genetic diversity and lack of molecular evidence for hemoplasma cross-species transmission between wild and synanthropic mammals from Central-Western Brazil. Acta Trop 2020; 203: 105303. http://dx.doi.org/10.1016/j.actatropica.2019.105303. PMid:31857081.

Guimarães A, Raimundo JM, Silva AT, Carpintero FM, Pires JR, Benevenute JL, et al. Detection of a putative novel genotype of Ehrlichia sp. from opossums (Didelphis aurita) from Brazil. Rev Bras Parasitol Vet 2019; 28(1): 140-144. http://dx.doi.org/10.1590/ s1984-296120180068. PMid:30427523.

Hoelzle K, Winkler M, Kramer MM, Wittenbrink MM, Dieckmann SM, Hoelzle LE. Detection of Candidatus Mycoplasma haemobos in cattle with anaemia. Vet J 2011; 187(3): 408-410. http://dx.doi.org/10.1016/j.tvjl.2010.01.016. PMid:20188610.

Horta MC, Moraes-Filho J, Casagrande RA, Saito TB, Rosa SC, Ogrzewalska M, et al. Experimental infection of opossums Didelphis aurita by Rickettsia rickettsii and evaluation of the transmission of the infection to ticks Amblyomma cajennense. Vector Borne Zoonotic Dis 2009; 9(1): 109-118. http://dx.doi.org/10.1089/vbz.2008.0114. PMid:18945194.

Lopes MG, Muñoz-Leal S, de Lima JTR, Fournier GFSR, Acosta ICL, Martins TF, et al. Ticks, rickettsial and erlichial infection in small mammals from Atlantic forest remnants in northeastern Brazil. Int J Parasitol Parasites Wildl 2018; 7(3): 380-385. http://dx.doi. org/10.1016/j.ijppaw.2018.10.001. PMid:30370217.

Machado CAL, Vidotto O, Conrado FO, Santos NJR, Valente JDM, Barbosa IC, et al. Mycoplasma ovis infection in goat farms from northeastern Brazil. Comp Immunol Microbiol Infect Dis 2017; 55: 1-5. http://dx.doi.org/10.1016/j.cimid.2017.08.004. PMid:29127988.

Massini PF, Drozino RN, Otomura FH, Mongruel ACB, Valente JDM, Toledo MJO, et al. Detection of Hemotropic Mycoplasma sp. in white-eared opossums (Didelphis albiventris) from Southern Brazil. Rev Bras Parasitol Vet 2019; 28(4): 797-801. http://dx.doi. org/10.1590/s1984-29612019058. PMid:31390439.

Melo ALT, Aguiar DM, Spolidorio MG, Yoshinari NH, Matushima ER, Labruna MB, et al. Serological evidence of exposure to tickborne agents in opossums (Didelphis spp.) in the state of São Paulo, Brazil. Rev Bras Parasitol Vet 2016; 25(3): 348-352. http:// dx.doi.org/10.1590/S1984-29612016028. PMid:27276663.

MessickJB, Walker PG, Raphael W, Berent L, Shi X. 'Candidatus Mycoplasma haemodidelphidis' sp. nov., 'Candidatus Mycoplasma haemolamae' sp. nov. and Mycoplasma haemocanis comb. nov., haemotrophic parasites from a naturally infected opossum (Didelphis virginiana), alpaca (Lama pacos) and dog (Canis familiaris): phylogenetic and secondary structural relatedness of their 16S rRNA genes to other mycoplasmas. Int J Syst Evol Microbiol 2002; 52(3): 693-698. http://dx.doi.org/10.1099/00207713-52-3693. PMid:12054227.

Mongruel ACB, Spanhol VC, Valente JDM, Porto PP, Ogawa L, Otomura FH, et al. Survey of vector-borne and nematode parasites involved in the etiology of anemic syndrome in sheep from Southern Brazil. Rev Bras Parasitol Vet 2020; 29(3): e007320. http:// dx.doi.org/10.1590/s1984-29612020062. PMid:32935770.

Nascimento CC, Horta MC. Didelphimorphia (Gambá, Cuíca). In: Cubas ZS, Silva JCR., Catão-Dias JL, editors. Tratado de animais selvagens: medicina veterinária. 2. ed. São Paulo: Roca; 2014. (vol. 1).

Parola P, Roux V, Camicas JL, Baradji I, Brouqui P, Raoult D. Detection of ehrlichiae in African ticks by polymerase chain reaction. Trans R Soc Trop Med Hyg 2000; 94(6): 707-708. http://dx.doi.org/10.1016/S0035-9203(00)90243-8. PMid:11198664.

Pontarolo GH, Kühl LF, Pedrassani D, Campos M, Figueiredo FB, Valente JDM, et al. 'Candidatus Mycoplasma haemoalbiventris', a novel hemoplasma species in white-eared opossums (Didelphis albiventris) from Brazil. Transbound Emerg Dis 2021; 68(2): 565572. http://dx.doi.org/10.1111/tbed.13716. PMid:32644252.

Regendanz P, Kikuth W. Sur un parasite du sang des "Quica" (Metachirus quica) Nuttallia brasiliensis n. sp., et influence de la rate sur les infections latentes du sang. C R H Seanc Mem Soc Biol 1928; 98: 1567.

Soares HS, Marcili A, Barbieri ARM, Minervino AHH, Moreira TR, Gennari SM, et al. Novel piroplasmid and Hepatozoon organisms infecting the wildlife of two regions of the Brazilian Amazon. Int J Parasitol Parasites Wildl 2017; 6(2): 115-121. http://dx.doi. org/10.1016/j.ijppaw.2017.05.002. PMid:28603688.

Valente JDM, Mongruel ACB, Machado CAL, Chiyo L, Leandro AS, Britto AS, et al. Tick-borne pathogens in carthorses from Foz do Iguaçu City, Paraná State, southern Brazil: A tri-border area of Brazil, Paraguay and Argentina. Vet Parasito/ $2019 ; 273: 71-79$. http://dx.doi.org/10.1016/j.vetpar.2019.08.008. PMid:31446256.

Valente JDM, Silva PW, Arzua M, Barros-Battesti DM, Martins TF, Silva AM, et al. Records of ticks (Acari: Ixodidae) on humans and distribution of spotted-fever cases and its tick vectors in Paraná State, southern Brazil. Ticks Tick Borne Dis 2020; 11 (6): 101510. http://dx.doi.org/10.1016/j.ttbdis.2020.101510. PMid:32993930. 
Vieira TSWJ, Vieira RFC, Nascimento DAG, Tamekuni K, Toledo RS, Chandrashekar R, et al. Serosurvey of tick-borne pathogens in dogs from urban and rural areas from Parana State, Brazil. Rev Bras Parasito/ Vet 2013; 22(1): 104-109. http://dx.doi.org/10.1590/ S1984-29612013000100019. PMid:24252955.

Zecca IB, Hodo CL, Slack S, Auckland L, Hamer SA. Trypanosoma cruzi infections and associated pathology in urban-dwelling Virginia opossums (Didelphis virginiana). Int J Parasitol Parasites Wildl 2020; 11: 287-293. http://dx.doi.org/10.1016/j.ijppaw.2020.03.004. PMid:32215248. 